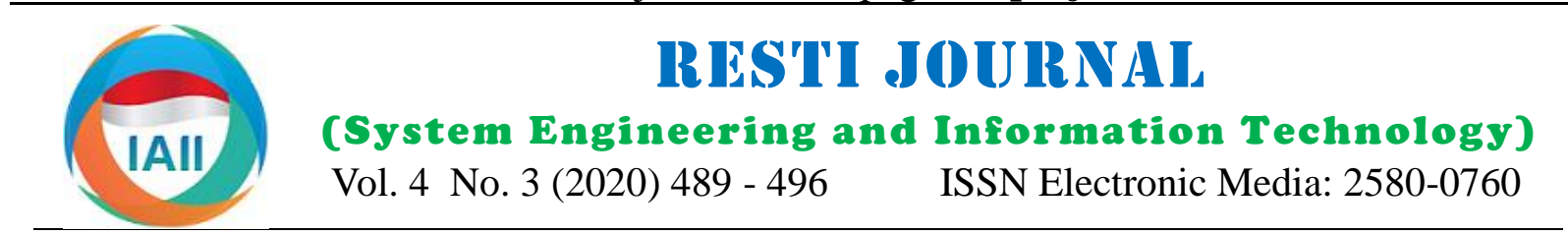

\title{
Educational Game in Learning Arabic Language for Modern Islamic Boarding School
}

\author{
Hasna Azizah ${ }^{1}$, Fatah Yasin Irsyadi ${ }^{2}$ \\ ${ }^{1,2}$ Informatic Study Program, Faculty of Communication and Information, Muhammadiyah University of Surakarta \\ 1zainhana249@gmail.com, 2fyai181@ums.ac.id
}

\begin{abstract}
Modern Islamic Boarding Schools began to implement the 2013 Curriculum without overriding the cottage materials sourced from Kitab. The Kitab used is written in Arabic. Even some Kitab are written without harakat, or commonly called bald Arab. Therefore, students have demands to memorize a lot of mufrodat (Arabic vocabulary) and have a heavier learning burden. Arabic is the key to understanding students in the matter of the lodge. Though the learning process is carried out conventionally and theoretically without interesting learning media. The purpose of making educational games in learning Arabic that is adapted to the Arabic curriculum is so that students can balance K13-based learning with teaching processes that are more effective, efficient, and enjoyable. Researchers chose Grade VII students as users in this educational game because they are the first level in the junior high school unit and to increase the attractiveness of students in learning Arabic. The application creation process uses Construct 2 software, Adobe Illustrator 2019 and Adobe Photoshop CS6. The results of this study, based on the results of User Acceptance Testing (UAT) show the average value of interpretation or user ratings of $89.92 \%$ which shows that the level of acceptance of respondents in the category of "Strongly Agree". The application can help students in memorizing mufrodat shown with an average percentage of 95.2\%. This result is supported by the research instrument in 9 questions about valid and reliable questionnaires that were tested using IBM SPSS Statistics 25 software.
\end{abstract}

Keywords: Educational Game, Arabic, Modern Islamic Boarding School, 2013 Curriculum (K13), Student

\section{Introduction}

Islamic boarding schools have transformed culture, systems and values, so they tend to break traditional traditions by transforming themselves into Modern Islamic Boarding Schools [1]. But by the public is still considered very backward in the mastery of technology, especially in the use of information technology for education [2]. Learning is done conventionally and theoretically without any interesting learning media. This reality is a problem faced by Islamic boarding school. Whereas Islamic boarding school has the potential for improvement when Law on National Education System No. 20 of 2003 Article 30 paragraph 4 places the position of Islamic boarding school in line with other educational institutions in Indonesia.

Now Islamic boarding schools are not only identical as Islamic educational institutions but also develop general knowledge. General science has been studied in an Islamic boarding school since independence in 1945 [3]. In its development, there are now some Islamic Boarding Schools implementing education based on the 2013 curriculum (K-13) without ignoring local content of the pondok sourced from the Kitab. The Kitab used is a book that reads Arabic not translation. Mastery of Arabic is the key to understanding the contents of the Kitab. The integration of the 2013 curriculum with the boarding school curriculum produces an integrated complementary style of curriculum [4] [5]. The K13 can be illustrated as a competency-based curriculum design, where its development continues to focus on achieving competencies that are formulated from standard competencies [6]. The application of the education standard for local content of the pondok and K13 makes students in modern boarding schools have a heavier study burden than school students in general.

Based on research conducted by [7], the highest problem map faced by modern Islamic boarding school students is on study habits. Aspects of this learning habit problem include learning difficulties, difficulty focusing (concentration) and experiencing learning disabilities. Demanding students to be able to master religious and general subjects will create higher education system standards and be one of the external factors causing academic stress [8]. Some students who cannot survive

Accepted by editor: 16-04-2020 | Final Revision: 24-05-2020 | Online Publication : 20-06-2020 
with existing academic demands will decide to leave the boarding school.

In the world of education, technology has its role in the teaching and learning process, including learning through game media [9]. Several studies have shown the positive effects of video games on some cognitive processes, such as perception skills, visual and spatial abilities, short-term memory, attention and reaction time, and some generalizing effects on other tasks [10]. There is increasing evidence that using games to train and educate is effective [11]. Educational games are very interesting to develop compared to using conventional educational methods. The development of the game world has penetrated in fields other than entertainment [12].

In the previous study [13], making educational games for Elementary School Arabic Language lessons with a case study in SDIT An Nahl Jambi City assisted the learning process of conventional methods, in the design process used Adobe Flash CS6 which was equipped with images and audio. In the process of developing attention to the functional and non-functional requirements of the system. Among the non-functional requirements of the system were usability, functionality, and performance. Another study [14] designed the application of Arabic Language learning media for early childhood called Rebula by taking samples in children of the Al-Qur'an Education Park (TPA). The conclusion obtained from this application is the educational game can add unfamiliar vocabularies including the Arabic Language because it is equipped with images and audio. This study used SO based on Android studio. Some studies also developed games as learning media such as educational games as learning media for early childhood education by using Kinect [15] and Mystical Weapons of Nusantara which was created to introduce the traditional weapons by using MDA Framework [16].

Making useful games, first of all, it begins with the reason why the game is made [17]. However, further research on educational game media needs to be applied in the modern Islamic boarding school. Several previous studies have not yet found a serious study of gamification of Arabic lessons in Modern Islamic Boarding Schools. Arabic language learning media based on educational games is so minimal and rarely encountered. This research will develop an educational game as an Arabic learning tool in modern Islamic boarding school as an effective, efficient and fun learning medium that is interesting to learn how the gamification effects of learning Arabic content of local Islamic boarding schools on classroom learning. The game was made using construct 2 .

\section{Research Method}

This research was conducted at the Imam Syuhodo Modern Islamic Boarding School. The affordable population in this study were student of class VII at Imam Syuhodo Modern Islamic Boarding School. Educational Game Learning Arabic Language developed with edutainment games because it emphasizes the educational side and also the entertainment side [18]. This material is adjusted from the Arabic Language guide book of durusullughoh al 'arobiyyah by Imam Zarkasyi and Imam Syabani used by the boarding school. Game Development Life Cycle (GDLC) is guidelines for developing a game. There are four GDLCs [19], in developing this educational game the researcher chose The Game Development Life Cycle (GDLC) as defined by Heather Chandler. The GDLC used is shown in Figure 1.

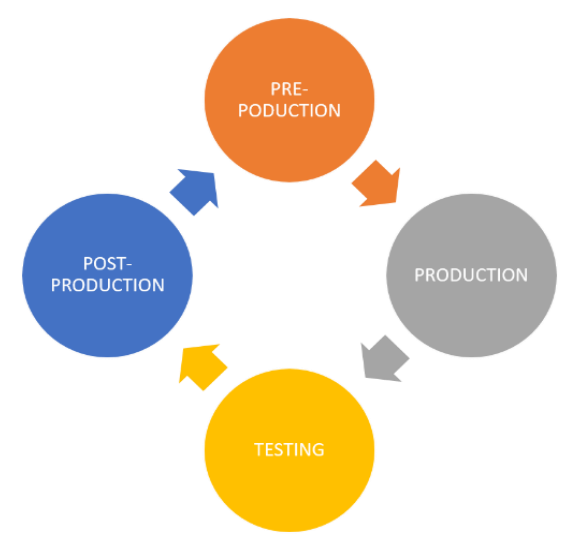

Figure 1. Stage in Game Development

\subsection{Pre-Production}

The pre-production stage involves creating game designs and making game prototypes such as defining game genres, gameplay, mechanical/conventional games, storylines, characters, challenges, fun factors, technical aspects, and documentation of the elements in the Game Design Document (GDD) [20].

\subsubsection{Storyline}

The game consists of 2 materials, namely color and shape. This is a request from the teacher, when researchers conduct observations and interviews in Islamic boarding schools. The selected material has never been taught in class before. In each color and shape menu is divided into two main menus namely material and color. The material menu contains material that will be used as material in educational game play. The game menu consists of the easiest to most difficult levels. The concept of material and games that are applied in the shape and color menu is not much different.

\subsubsection{Storyboard}

Storyboard is an initial sketch drawing that is used as a planning tool to show how the game will be played. The storyboard game in learning Arabic Language can be seen in Table 1. It consists of 5 main scenes, with the following information: 


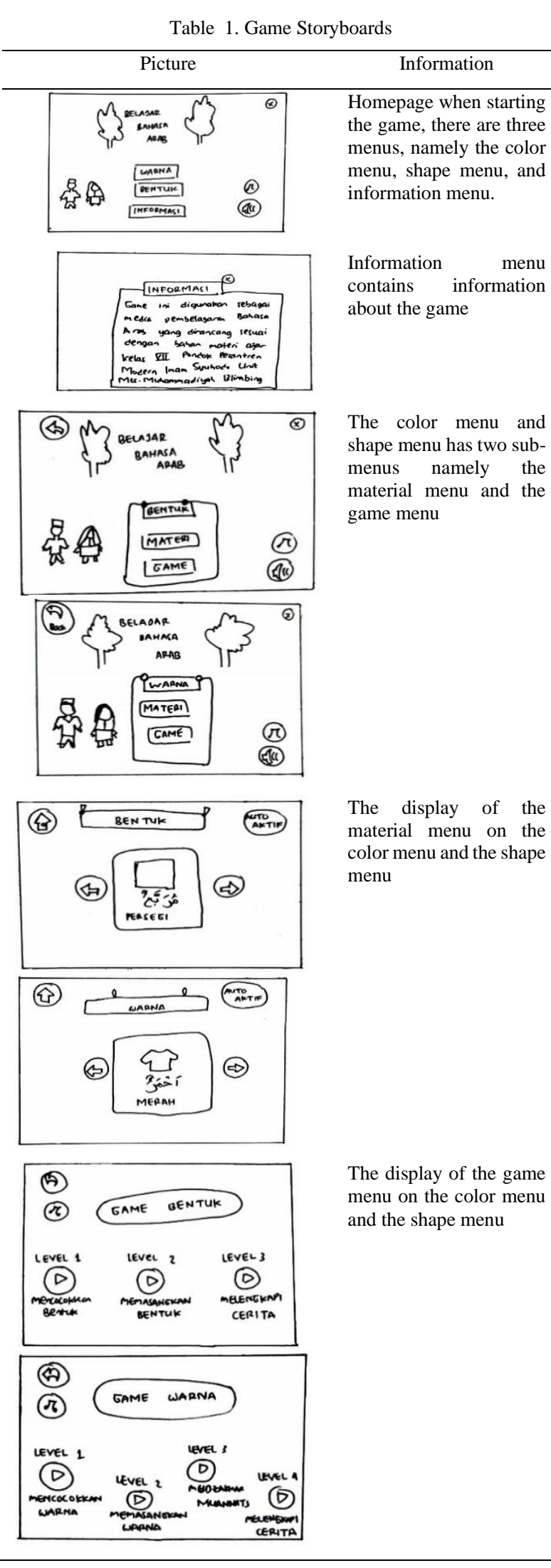

\subsection{Production}

The production phase is a refinement of the preproduction stage by implementing the concepts, designs, and plans contained in the Game Design Document (GDD) [21]. This stage also covers asset creation, programming and integration between assets and source code. The application creation process uses Construct 2 software and asset game created using Adobe Illustrator 2019 and Adobe Photoshop CS6.

Making an application starts from the display home application, material menu and game menu. The material menu is taken from the manual used and created with concepts that make it easy for the teacher to teach in class. In the game menu, the level starts from the easiest and most basic level and then rises to the harder level. The level game makes student practice problem solving.

\subsection{Testing}

System testing was done by the Black Box method. Black box testing is chosen for validation with a focus solely on the output generated in response to the selected input and execution conditions [22]. The test is done using a desktop with Windows 10 Operating System. The test results show that the educational game is running well in the target application. After testing using blackbox testing, the educational game was made into a learning medium in modern boarding schools based on the following steps guide.

The method of learning educational games in modern boarding schools begins with an analysis of hardware requirements. This is because not all modern boarding schools provide computer laboratories. The absence of a computer lab can be replaced with a laptop. Sound need to be prepared if needed. This method cannot be separated from the role of the teacher, because the teacher is involved in learning in class from beginning to end. The teacher explains the scope of the material to students so that students focus on the current discussion. The game application is operated waiting for instructions from the teacher. Before explaining the material in the material menu in the game, the teacher explains the function buttons of the game. In every educational game there are game instructions, so the teacher only needs to explain what already exists. After that, students work on the questions in the educational game from the easiest level to the most difficult. When students work on problems in this game, interactive learning will occur. Where students will compete to complete the levels in the game. The teacher becomes a facilitator when students encounter difficulties while working. In such conditions, students will not get bored in class because learning is effective, efficient, and fun. Students who complete the game level early can help other students who are struggling. This will train students' collaboration in solving problems. 


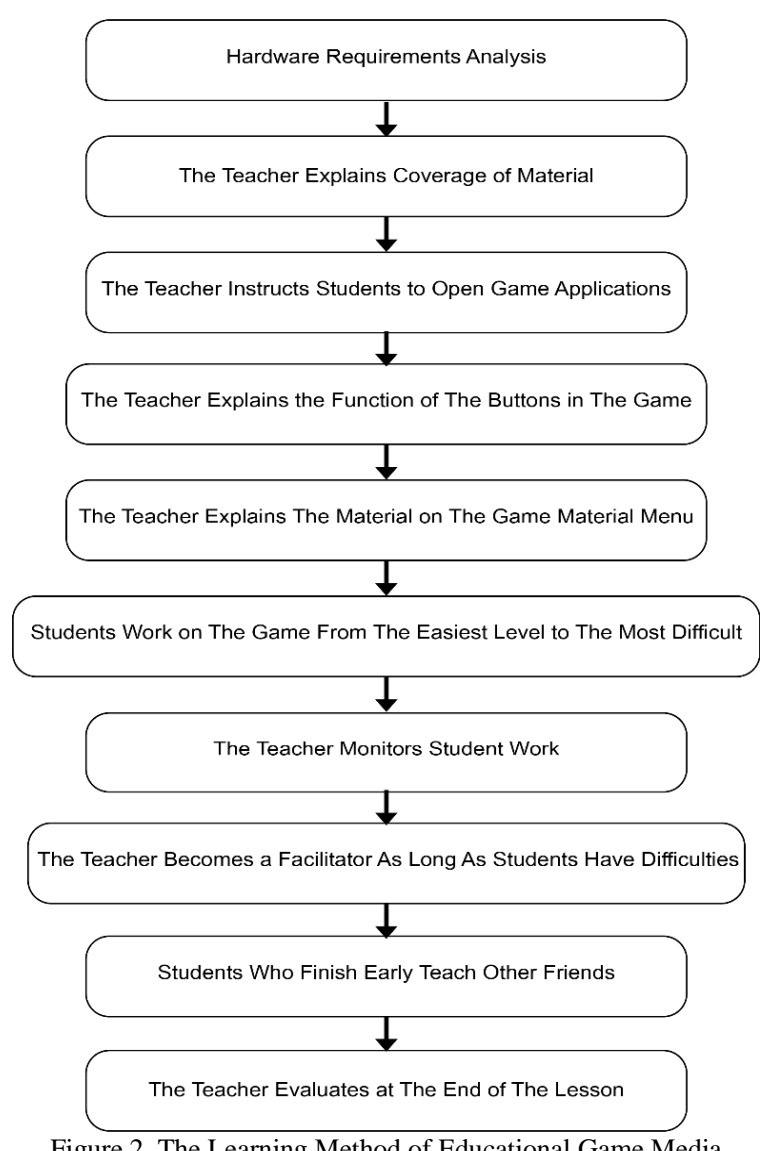

Figure 2. The Learning Method of Educational Game Media

When compared with learning that is usually done in class, the teacher focuses on the material in the book and translates it one by one into Indonesian so that learning is teacher base learning. The teacher base learning method positions students like a sponge that absorbs all information from the teacher [23] and is used as an object. The impact is students in the class become passive and have low motivation in understanding the material. This educational game learning media combines teacher centered and student center, resulting in new collaborations with better results.

\subsection{Post-Production}

Post Production stage consists of post mortem and archive plans [24]. After testing the game, maintenance is carried out if at any time there are bugs or errors so that they are immediately handled and handled.

\section{Result and Discussion}

\subsection{Application Display}

On the main menu page there is a menu of colors, shapes, information, instructions, exits, sound buttons and music buttons. The information menu contains a notification of the source of material used in the game. The Help menu contains instructions for using buttons in the game. The sound and music buttons are used to activate and deactivate sounds and music in the game.

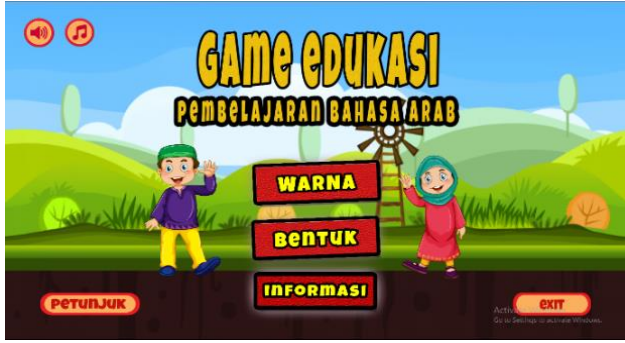

Figure 3. Homeplay Display of the Game
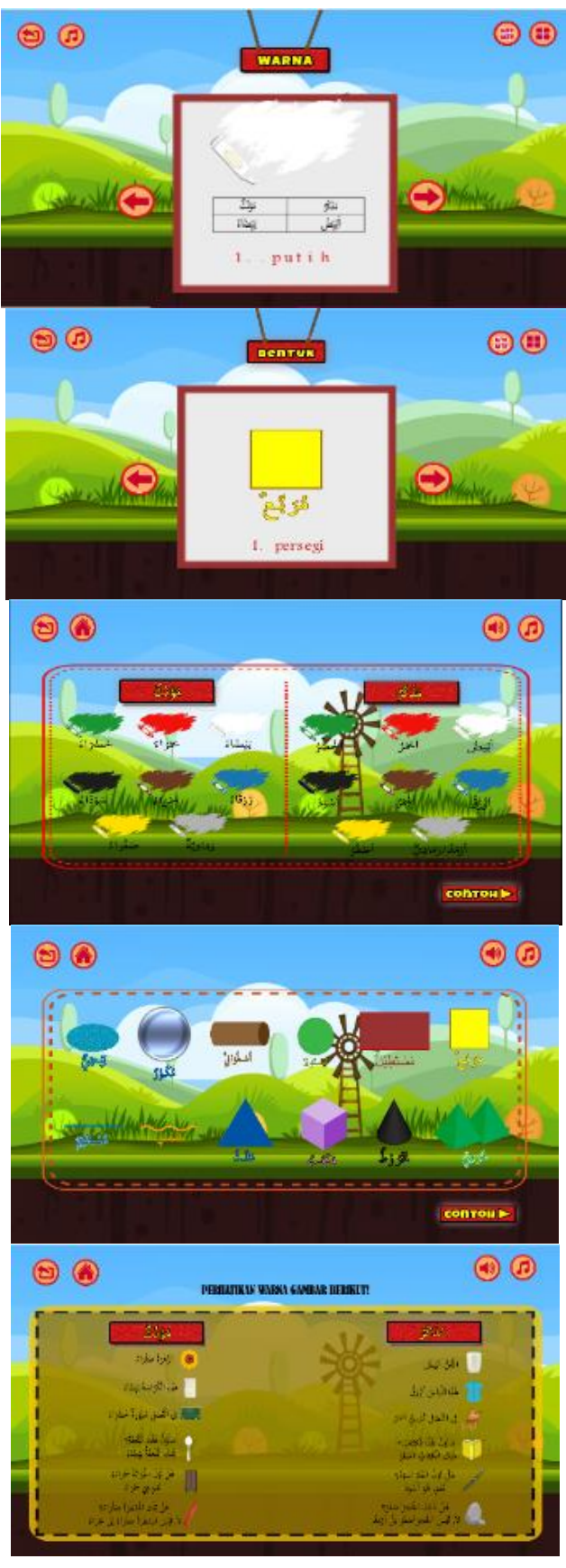

Figure 4. Material Menu Display on the Color and Shape

Figure 4 is a display of color and shape material. Display the material menu on colors and shapes made simple and attractive by involving images and audio. This audio is 
a mufrodat of the displayed image. Material delivered via audiovisual makes learning achieve maximum results [12]. On the material menu there are examples of using mufrodat, which students can learn so they can solve existing game menu problems.
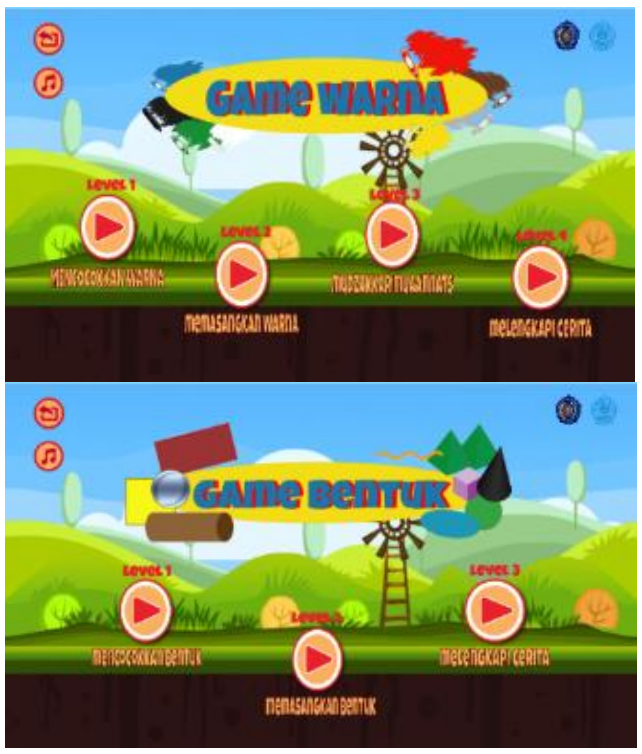

Figure 5. Display of The Game Menu Color and Shape

Figure 5 is a display of the game menu of color and shape. The game is done from the easiest level, level one. The higher the level, the higher the level of difficulty. To be able to complete the game to the final level requires mastery of the mufrodat and understanding of this material.

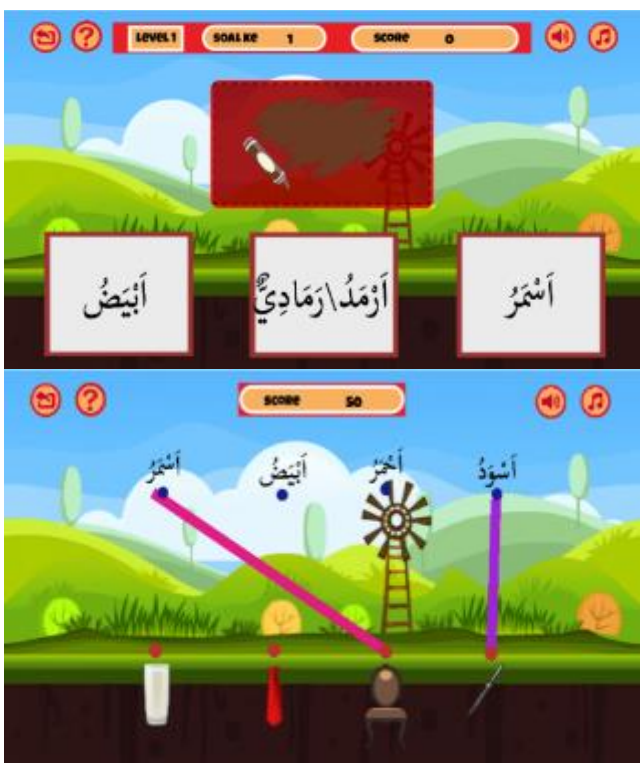

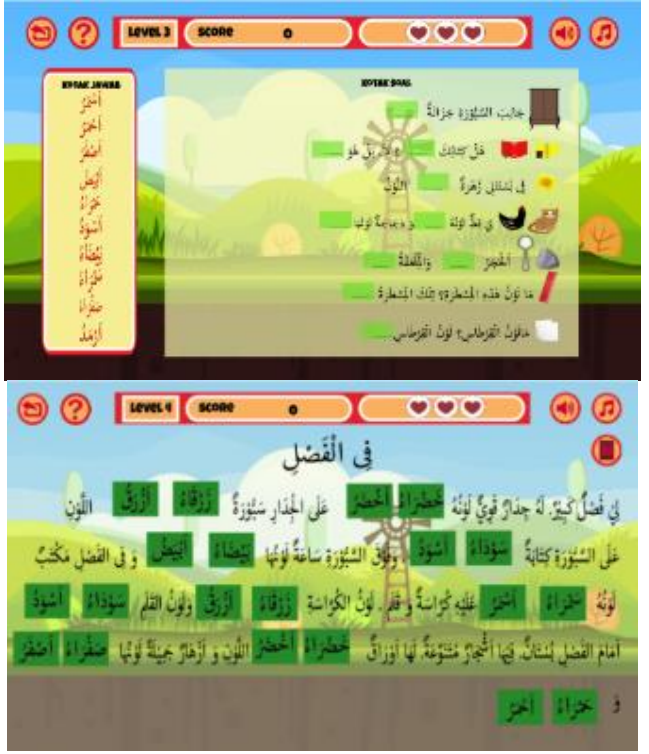

Figure 6. Level 1-4 Game Display in The Color Menu

Figure 6 is a display of game levels one to four in the color menu. Level one is a mix and match game where students only need to drag and drop colors to match the existing consensus. Level two uses the game connecting points between mufrodat and colors on objects. The correct answer can no longer be changed. Level 3 students must drag and drop the appropriate mufrodat into an Arabic sentence and each mistake will reduce one life out of the three existing lives. Level four is the most difficult level, where students must choose the right mufrodat to complete the existing story.

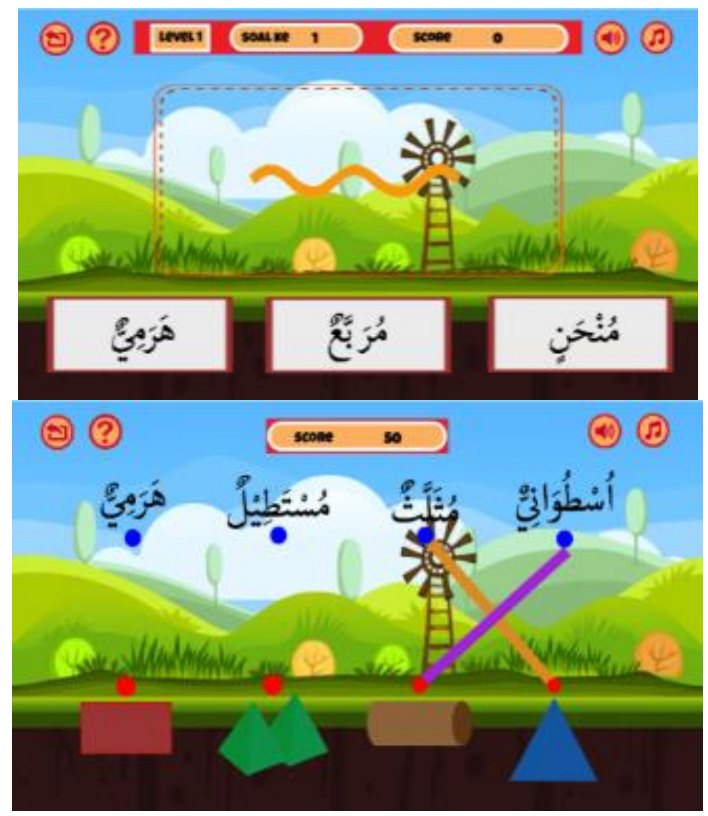




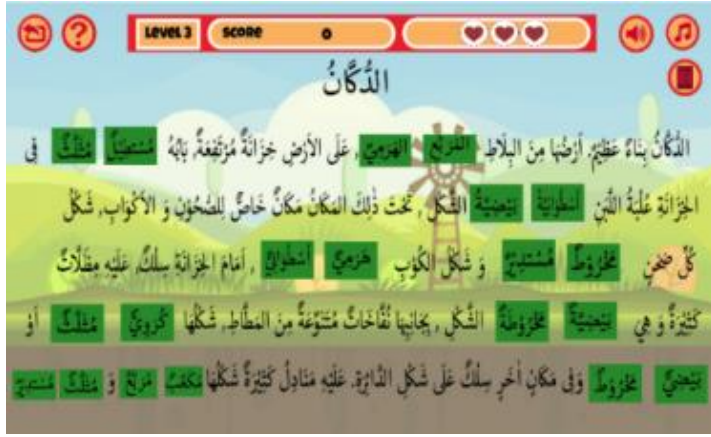

Figure 7. Level 1-3 Game Display in The Shape Menu

7
8
9

increased with the educational game

the level of interest

in the Arabic

Language can

increase after

playing an

education game

educational game

can help memorize

mufrodat in an

efficient and fun

way

the enthusiasm of

students when

$\begin{array}{lllllllll}\text { learning with } & 25 & 17 & 4 & 0 & 0 & 205 & 89.1 \%\end{array}$

educational games

increase

concept of game level one mix and macth, level two connecting points game and level 3 students must choose the right mufrodat to complete the existing story. The The formula for calculating the average value concept of the game menu of shapes and colors are not percentage using equation (2):

much different.

\subsection{User Acceptance Test Results}

$$
\text { Average Value Percentage }=\sum_{i=1}^{n} \frac{x i}{N}
$$

This study uses a questionnaire to see user ratings of Notation:

applications that have been made. Questionnaire testing $\mathrm{xi}=$ Total PercentageValue

was conducted in two classes of Imam Syuhodo's $\mathrm{N}=$ Number of Questions

modern Islamic boarding school with a total of 46

students. The questionnaire was given after the game

was tested. The questionnaire uses 5 Likert scale with positive statements that are given a score of 5,4,3,2,1 in the form of answers of Strongly Agree (SA), Agree (A), Neutral (N), Disagree (D), Strongly Disagree (SD) [25]. The ideal score is obtained by multiplying the number of respondents by 5 [14]. The ideal score in this study is $46 \times 5=230$. The process of calculating the percentage value uses the equation formula 1.

$$
\text { Persentasi Nilai }=\frac{\text { Total Skor }}{\text { Skor Ideal }} \times 100 \%
$$

The Average value percentage $=809.3 / 46=89.92$.

Interpretations of each Likert scale can be shown in table 3 [26].

\begin{tabular}{lll}
\multicolumn{3}{c}{ Table 3. Likert Scale Interpretation } \\
\hline Likert Score & $\begin{array}{l}\text { Interpretation } \\
\text { of scores with } \\
\text { intervals }=20\end{array}$ & Option \\
\hline 1 & $0 \%-19.99 \%$ & Strongly Disagree \\
2 & $20 \%-39.99 \%$ & Disagree \\
3 & $40 \%-59.99 \%$ & Neutral \\
4 & $60 \%-79.99 \%$ & Agree \\
5 & $80 \%-100 \%$ & Strongly Agree \\
\hline
\end{tabular}

Types of scale questions Questionnaire results used are shown in table 2 .

Note: The interval $=20$ is obtained from dividing the value of 100 by the number of Likert scores

\begin{tabular}{|c|c|c|c|c|c|c|c|c|}
\hline \multirow{2}{*}{ No } & \multirow{2}{*}{ Questions } & \multicolumn{5}{|c|}{ Answer Choice } & \multirow{2}{*}{$\begin{array}{c}\text { Total } \\
\text { Scor } \\
\text { e }\end{array}$} & \multirow{2}{*}{$\begin{array}{l}\text { Value } \\
\text { Percen } \\
\text { age }\end{array}$} \\
\hline & & SA & A & $\mathrm{N}$ & $\mathrm{D}$ & SD & & \\
\hline 1 & $\begin{array}{l}\text { the display of the } \\
\text { game application } \\
\text { is interesting }\end{array}$ & 28 & 16 & 2 & 0 & 0 & 210 & 91.39 \\
\hline 2 & $\begin{array}{l}\text { the menus and } \\
\text { buttons in the } \\
\text { application easy to } \\
\text { understand }\end{array}$ & 23 & 14 & 8 & 1 & 0 & 197 & $85.6 \%$ \\
\hline 3 & $\begin{array}{l}\text { the game } \\
\text { application easy to } \\
\text { play and not } \\
\text { boring }\end{array}$ & 25 & 13 & 8 & 0 & 0 & 201 & $87.4 \%$ \\
\hline 4 & $\begin{array}{l}\text { the application can } \\
\text { help students in } \\
\text { memorizing } \\
\text { mufrodat }\end{array}$ & 36 & 9 & 1 & 0 & 0 & 219 & $95.2 \%$ \\
\hline 5 & $\begin{array}{l}\text { the game } \\
\text { instruction in the } \\
\text { application clear }\end{array}$ & 32 & 12 & 2 & 0 & 0 & 214 & $93 \%$ \\
\hline 6 & $\begin{array}{l}\text { Language } \\
\text { understanding be }\end{array}$ & 26 & 15 & 5 & 0 & 0 & 205 & $89.1 \%$ \\
\hline
\end{tabular}

Table 2. Application Test Questionnaire Results
Calculation of the average value percentage using Equation 2 yields $89.92 \%$. This is within the range of
$80 \%-100 \%$, which is shows that the level of acceptance age of respondents in the Educational Games in Learning

Arabic Language is included in category of "Strongly Agree". According to table 2, if depicted in graphical form as shown in the following figure 8 .

\section{Application Test Questionnaire Results}

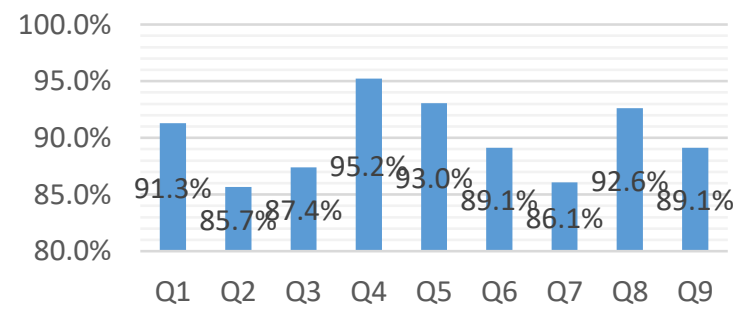

RESTI Journal (System Engineering and Information Technology) Vol. 4 No. 3 (2020) 489 - 496 


\subsection{Validity Test}

A validity test was used to determine whether the The application of educational games for learning the research instrument items were valid or not by showing Arabic Language can be operated on a desktop with the extent to which a measuring instrument measures Windows 10 Operating System. Based on the results of precisely the concept to be measured [27]. Data User Acceptance Testing (UAT) shows the average collection in this study used questionnaires. The validity value of interpretation or user ratings of $89.92 \%$ which testing of the questionnaire in this study used the is shows that the level of acceptance of respondents in in product-moment correlation between the score of each category of "Strongly Agree". Very successful question with the total score. The test criteria were educational game helps learning in Modern Islamic carried out by comparing the $r_{\text {count }}$ with the $r_{\text {table }}$ at the Boarding Schools more effectively, efficiently and fun level of $\alpha=5 \%$ and $\alpha=1 \%$. This study uses a significant combining the collaboration method of teacher base level $(\alpha)=0.05$. The number of samples $(n)=46$ learning and student base learning. The application can respondents, sortable obtained by 0.291 .

Table 4. Result of the Validity Test

\begin{tabular}{cccc}
\hline $\begin{array}{c}\text { Correlation } \\
\text { Between }\end{array}$ & $\begin{array}{c}\text { Correlation } \\
\text { Value }\end{array}$ & $\mathrm{r}_{\text {tabel }}$ Value & $\begin{array}{c}\text { Conclusio } \\
\text { Q1 on total }\end{array}$ \\
\hline Q,700 & 0,291 & Valid \\
Q2 on total & 0,599 & 0,291 & Valid \\
Q3 on total & 0,689 & 0,291 & Valid \\
Q4 on total & 0,456 & 0,291 & Valid \\
Q5 on total & 0,508 & 0,291 & Valid \\
Q6 on total & 0,560 & 0,291 & Valid \\
Q7 on total & 0,628 & 0,291 & Valid \\
Q8 on total & 0,638 & 0,291 & Valid \\
Q9 on total & 0,735 & 0,291 & \\
\hline
\end{tabular}

The instrument was declared valid if $r_{\text {count }}>r_{\text {table }}$ and declared invalid if $r_{\text {count }}<r_{\text {table. The data tested were }}$ students questionnaire data with a total of 46 respondents or $\mathrm{N}=46$ and 9 items of questions. The testing was done using IBM SPSS Statistics 25 software. The result of the validity test showed that all questions were valid. Based on the validity test showed that the results of the questionnaire can be trusted and can be used as a data collection tool.

\subsection{Reliability Test}

A reliability test is used to measure the extent to which the results of a measurement can be trusted so that a level of consistency is obtained if measurements are made using the questionnaire repeatedly. Measurement is made using the Cronbach Alpha formula developed by Cronbach following Equation (3).

$$
r_{11}=\left[\frac{n}{(n-1)}\right]\left[1-\frac{\sum a_{i}^{2}}{a_{t}^{2}}\right]
$$

Notation:

$$
\begin{aligned}
& \mathrm{r}_{11}=\text { instrument reliability } \\
& \sum a_{i}^{2}=\text { score of each item } \\
& n \quad=\text { the number of items } \\
& a_{t}^{2}=\text { total variant }
\end{aligned}
$$

The instrument was declared reliable with the minimum Cronbach Alpha value set of 0.6. If the Cronbach Alpha value obtained from the SPSS calculation results was greater than 0.6 then the questionnaire was reliable. The results of the questionnaire reliability test showed a Cronbach Alpha of 0.786. Therefore, it can be concluded that the research instrument used was reliable. help students in memorizing mufrodat shown with an average percentage of $95.2 \%$. This result is supported by the research instrument in 9 questions about valid and reliable questionnaires that were tested using IBM SPSS Statistics 25 software.

\section{References}

[1] U. Sholihah, "Peran Ict Dalam Modernisasi Pendidikan Pondok Pesantren," Cendekia J. Kependidikan dan Kemasyarakatan, vol. 10, no. 1, p. 15, 2012.

[2] M. Arif, "Perkembangan Pesantren Di Era Teknologi," $J$. Pendidik. Islam, vol. 28, no. 2, p. 307, 2016.

[3] B. B. Manti, A. Husaini, E. Mujahidin, and D. Hafidhuddin, "Konsep Pendidikan Modern Mahmud Yunus dan Kontribusinya Bagi Lembaga Pendidikan Islam di Indonesia," Ta'dibuna J. Pendidik. Islam, vol. 5, no. 2, p. 151, 2016.

[4] N. Agus, "Integrasi kurikulum 2013 dan kurikulum pondok pesantren serta implementasinya di MTs Fadllillah Tambak Sumur Waru Sidoarjo," 2017.

[5] J. Paminto, T. Rosiana, and H. Triluqman Budisantoso, "Indonesian Journal of Curriculum and Educational Technology Studies Implementasi Kurikulum 2013 di Sekolah Pesantren dengan Sistem Boarding School," Ijcets, vol. 6, no. 1, pp. 41-52, 2018.

[6] D. Rumahlatu, E. K. Huliselan, and J. Takaria, "An analysis of the readiness and implementation of 2013 curriculum in the west part of Seram District, Maluku Province, Indonesia," Int. J. Environ. Sci. Educ., vol. 11, no. 12, pp. 5662-5675, 2016.

[7] P. Masalah et al., "Aregina Nabella Abstrak," no. 111, pp. 7178, 2014. Konseling dan Pendidik., vol. 5, no. 3, p. 143, 2017.

[9]; Y I Kurniawan F Y Al Irsyadi; R Annas, "Game Edukasi Pembelajaran Bahasa Inggris untuk Pengenalan Benda-Benda di Rumah bagi Siswa Kelas 4 Sekolah Dasar," vol. 9, no. September, pp. 78-92, 2019.

[10] S. Gree and D. Bevalier, "Action Video Game Modifies Visual Selective Attention," Nature, vol. 423, no. May, pp. 534-537, 2003.

[11] L. Pannese and D. Morosini, "Serious Games to support Reflection in the HealthCare Sector," Int. J. Serious Games, vol. 1, no. 3, pp. 5-14, 2014.

[12] M. S. Khairy, D. Herumurti, and I. Kuswardayan, "Analisis Pengaruh Penggunaan Game Edukasi pada Penguasaan Kosakata Bahasa Asing dengan Studi Kasus Game Edukasi Bahasa Arab," Khazanah Inform. J. Ilmu Komput. dan Inform., vol. 2, no. 2, p. 42, 2016.

[13] M. rivai, I. sani wijaya, and $M$. Istoningtias, "PERANCANGAN APLIKASI GAME EDUKASI PENGENALAN BAHASA ARAB BERBASI ANDROID (Studi Kasus: Sekolah Dasar Islam Terpadu An-Nahl)," J. Process. Vol 10 No 1 Process., Aug. 2017.

14] D. A. Puspa Putri, "Rancang Bangun Media Pembelajaran Bahasa Arab Untuk Anak Usia Dini Berbasis Android," Technol. J. Ilm., vol. 10, no. 3, p. 156, 2019.
[8] M. Barseli and I. Ifdil, "Konsep Stres Akademik Siswa," J. 
Hasna Azizah, Fatah Yasin Irsyadi

RESTI Journal (System Engineering and Information Technology) Vol. 4 No. 3 (2020) 489 - 496

[15] F. Y. Al Irsyadi and Y. S. Nugroho, "Game Edukasi Pengenalan Anggota Tubuh Dan Pengenalan Angka Untuk Anak Berkebutuhan Khusus (ABK) Tunagrahita Berbasis Kinect," Pros. SNATIF, vol. 2, pp. 1-8, 2015.

[16] L. Husniah, F. Fannani, A. S. Kholimi, and A. E. Kristanto, "Game Development to Introduce Indonesian Traditional Weapons using MDA Framework," Kinet. Game Technol. Inf. Syst. Comput. Network, Comput. Electron. Control, vol. 4, no. 1, pp. 27-36, 2018.

[17] J. Arjoranta, "How to Define Games and Why We Need to," Comput. Games J., vol. 8, no. 3-4, pp. 109-120, 2019.

[18] D. Masa and K. Masa, "Kajian Pustaka Perkembangan Genre Games Dari Masa Ke Masa," vol. 1, no. 2, pp. 113-1134, 2015.

[19] R. Ramadan and Y. Widyani, "Game development life cycle guidelines," 2013 Int. Conf. Adv. Comput. Sci. Inf. Syst. ICACSIS 2013, pp. 95-100, 2013.

[20] R. A. Krisdiawan, "Implementasi Model Pengembangan Sistem Gdlc Dan Algoritma Linear Congruential Generator Pada Game Puzzle," Nuansa Inform., vol. 12, no. 2, pp. 1-9, 2018.

[21] L. Husniah, B. F. Pratama, and H. Wibowo, "Gamification And GDLC (Game Development Life Cycle) Application For Designing The Sumbawa Folklore Game "The Legend Of Tanjung Menangis (Crying Cape)"," Kinet. Game Technol. Inf.
Syst. Comput. Network, Comput. Electron. Control, vol. 3, no. 4, pp. 351-358, 2018.

[22] M. Larrea, "Black-Box Testing Technique for Information Visualization. Sequencing Constraints with Low-Level Interactions," J. Comput. Sci. Technol., vol. 17, no. 1, pp. 3748, 2017.

[23] SUSAN VERNER, "Making the Shift: Moving from a Teacher Centered Classroom to a Student Centered Classroom," vol. 12, no. June, pp. 13-14, 2018.

[24] R. Sistem, H. Prasetiyo, I. Widaningrum, and I. P. Astuti, "Game Edukasi Math \& Trash Berbasis Android dengan Menggunakan,” J. RESTI (Rekayasa Sist. dan Teknol. Informasi), vol. 1, no. 10, pp. 5-11, 2021.

[25] A. Febtriko and I. Puspitasari, "Mengukur Kreatifitas Dan Kualitas Pemograman Pada Siswa Smk Kota Pekanbaru Jurusan Teknik Komputer Jaringan Dengan Simulasi Robot," Rabit J. Teknol. dan Sist. Inf. Univrab, vol. 3, no. 1, pp. 1-9, 2018.

[26] W. S. Wardhono, L. P. Kusuma, and W. S. Wardhono, "Evaluasi User Acceptance Augmented Reality Triage Mobile Pada Sistem Kedaruratan Medis," J. Sentar, pp. 978-979, 2015.

27] F. Yusup, "Uji Validitas dan Reliabilitas Instrumen Penelitian Kuantitatif," J. Tarb. J. Ilm. Kependidikan, vol. 7, no. 1, pp. 17-23, 2018. 